\title{
Fetal Growth and Neurobehavioral Outcomes in Childhood
}

Pinka Chatterji, Kajal Lahiri, and Dohyung Kim

University at Albany, State University of New York

\begin{abstract}
Using a sample of sibling pairs from a nationally representative U.S. survey, we examine the effects of the fetal growth rate on a set of neurobehavioral outcomes in childhood measured by parent-reported diagnosed developmental disabilities and behavior problems. Based on models that include mother fixed effects, we find that the fetal growth rate, a marker for the fetal environment, is negatively associated with lifetime diagnosis of developmental delay. We also find that the fetal growth rate is negatively associated with disruptive behaviors among male children. These results suggest that developmental disabilities and problem behaviors may play a role in explaining the well-documented association between birth weight and human capital outcomes measured in adulthood.
\end{abstract}

\section{Keywords}

Low birth weight; Fetal growth; Neurobehavioral outcomes; Developmental disabilities; Behavior Problems Index (BPI)

\section{Introduction and Background}

It is well-documented that birth weight has a lasting impact on human capital outcomes measured later in the life course such as educational achievement and labor market outcomes (Behrman et al., 2004; Black et al., 2007; Oreopoulos et al., 2008; Royer, 2009). Prior research indicates that cognitive ability may play an important mediating role in this association between birth weight and human capital outcomes by determining the rate of return on educational investments and an individual's productivity in the labor market (Strauss, 2000; Matte et al., 2001; Boardman et al., 2002; Black et al., 2007; Johnson and Schoeni, 2007; Torche and Echevarŕla, 2011; Figlio et al., 2013; Cook \& Fletcher, 2014). Recent evidence, however, suggests that noncognitive abilities and mental health may be as important as cognitive abilities in determining human capital outcomes. For example, Lindquist and Westman (2011) using data from military enlistees in Sweden find that both cognitive and noncognitive skills are associated with earnings, but noncognitive skills actually matter more at the lowest part of the earnings distribution. Currie and Stabile (2006) find a large deficit in test scores and educational achievement among children having

(C) 2014 Elsevier B.V. All rights reserved

Publisher's Disclaimer: This is a PDF file of an unedited manuscript that has been accepted for publication. As a service to our customers we are providing this early version of the manuscript. The manuscript will undergo copyediting, typesetting, and review of the resulting proof before it is published in its final citable form. Please note that during the production process errors may be discovered which could affect the content, and all legal disclaimers that apply to the journal pertain. 
symptoms of Attention Deficit Hyperactivity Disorder (ADHD), which is one of the most common developmental disabilities in the United States. These findings suggest that the effect of birth weight on noncognitive outcomes in childhood may constitute another mechanism through which birth weight determines later human capital outcomes (Datta Gupta et al., 2013).

In this paper, we estimate the effect of birth weight on a set of noncognitive outcomes termed neurobehavioral outcomes; this category includes behavior problems and diagnosed developmental disabilities (Anderson et al., 2003). Early studies indicate that low birth weight is associated with neurobehavioral problems in childhood. For example, McCormick et al. (1992), using data from two multisite cohort studies of infants born in the late 1970's and early 1980's, find that low birth weight (less than $2.5 \mathrm{~kg}$ ) is associated with more mother-reported behavior problems, and very low birth weight (less than $1.5 \mathrm{~kg}$ ) is associated with higher risk for diagnosed learning problems. Similarly, Hoy et al. (1992), using data on infants born during the late 1970's and early 1980's at a hospital in Ireland, find that very low birth weight (less than $1.5 \mathrm{~kg}$ ) is associated with higher scores for meanness/unhappiness and social withdrawal, and less peer acceptance. These studies, however, are based on older data and do not include extensive controls for other observed variables that may be correlated with both birth weight and behavioral outcomes.

In a few more recent studies, researchers have included extensive controls for potential confounding factors that may be correlated with both behavior problems and low birth weight. Kelly et al. (2001) use the 1997 Health Survey for England and find a linear association between birth weight and behavior problems (measured using the Strengths and Difficulties Questionnaire) over the full birth weight distribution, after controlling for other factors, with lower birth weight children experiencing more problem behaviors than higher birth weight children. On the contrary, Corman and Chaikind (1998) use the 1988 National Health Interview Survey and find that low birth weight is not associated with an index of problem behaviors after controlling for socioeconomic status, although they find low birth weight children are more likely to repeat a grade in school and attend special education classes. Similarly, using the ALSPAC cohort in Bristol, United Kingdom, Wiles et al. (2006) show that the estimated effect of birth weight on behavior problems (also based on the Strengths and Difficulties Questionnaire) disappears after controlling for potential confounders including birth length and gestational age. Most recently, Datta Gupta et al. (2013) use a large panel data set of Danish children who are born around the same time and examine the potentially dynamic effects of birth weight on behavioral outcomes. They find some evidence that the adverse effects of low birth weight on behavior problems increase as children age, but the effect on overall behavior problems is statistically insignificant (Datta Gupta et al., 2013).

While some of these studies suggest that there may be omitted variables correlated with both birth weight and behavior problems, to our knowledge, existing studies do not directly address this problem. This is partly due to lack of data -- panel survey data which include behavioral outcomes information as well as data on siblings are scarce. On the other hand, one advantage of the cohort studies which have been used in previous research is they follow children born around the same time, allowing researchers to investigate dynamic 
effects, the approach taken by Datta Gupta et al. (2013). However, cohort data do not allow researchers to control for unobserved mother heterogeneity since these surveys necessarily exclude biological siblings.

In addition to this mixed evidence on birth weight and behavior problems among children, another strand of literature demonstrates an association between poor fetal growth and developmental disabilities in childhood such as ADHD and learning disability. ${ }^{*}$ In a comprehensive study that uses data from the 1997-2005 National Health Interview Survey (NHIS), Boulet et al. (2011) find that birth weight is negatively associated with a range of developmental disabilities in childhood including mental retardation, learning disability, ADHD, seizures, cerebral palsy, hearing impairment, and stuttering. Other studies attempt to control for omitted variable bias by comparing siblings or twins, but they tend to focus on specific conditions. Using a large sample of U.S. siblings, Fletcher (2012) finds heightened probability of self-reported learning disability and ADHD symptoms among low-birthweight children after controlling for family fixed effects. Within-twin studies provide stronger causal evidence regarding the association between fetal growth measured by birth weight and ADHD. Using a sample of Swedish twin pairs, Hultman et al. (2007) find that among male twins, the twin with a lower birth weight has a thirteen percent higher ADHDsymptom score than the other male twin at age 8 to 9 and a twelve percent higher score at age 13 to 14. It is notable that their findings are robust regardless of sex and zygosity. Similarly, Groen-Blokhuis et al. (2011) use a Dutch sample of twins and find positive and significant effects of low birth weight on the incidence of ADHD.

In this paper, we explore the association between fetal growth rate and a range of neurobehavioral outcomes using three waves of the Child Development Supplement of the Panel Study of Income Dynamics (PSID-CDS). ${ }^{*}$ We build on recent work by Datta Gupta et al. (2013), by using mother fixed effects (hereafter MFE) estimation to address unobserved family background and (to some extent) genetic factors that may be correlated with both birth weight and neurobehavioral outcomes. Also, because our models include both the fetal growth rate and a set of indicators for preterm birth, we attempt to separate out the effect of the fetal growth rate, which is known in the literature to better capture the accumulated net nutrition intake in utero, on neurobehavioral outcomes.

We also build on prior work by examining the effect of the fetal growth rate on a broader set of diagnosed developmental disabilities in childhood, while previous within-twin or withinsibling studies have focused on ADHD. Unlike other studies that relied on self-reported or mother-reported symptoms of developmental disabilities, we use both measures of diagnosis and symptom scores. Finally, since PSID-CDS respondents continue to be surveyed as they enter adulthood through the Transition into Adulthood (PSID-TA) survey, we are able to use the PSID-TA data to estimate the association between childhood behavioral outcomes and educational attainment in young adulthood. These models allow us to gauge whether or not

\footnotetext{
* See Nelson (2006) for an overview.

* The Panel Study of Income Dynamics is a public use dataset produced and distributed by the Survey Research Center, Institute for Social Research, University of Michigan, Ann Arbor, MI (1993-2009). See http://psidonline.isr.umich.edu/ for more information.
} 
neurobehavioral outcomes may be an important set of non-cognitive outcomes which act as mechanisms linking early health to human capital accumulation.

Results from our models which include mother fixed effects show that the fetal growth rate has negative and statistically significant effects on the risk of children having nonsensory developmental disabilities such as developmental delay and speech impairment, while very preterm birth (less than 32 weeks) is strongly and positively associated with vision difficulty. We also find that the fetal growth rate is negatively associated with disruptive conduct problems such as antisocial, oppositional, and hyperactive behaviors especially among boys. These disruptive conduct problems appear to be associated with a slight reduction in the likelihood of college entrance, even after controlling for cognitive ability. We caution, however, that these effects are small in magnitude and in some cases are not statistically significant across all model specifications. Nevertheless, on balance, our findings suggest that public policy interventions that improve birth outcomes may have long-term benefits by lowering risk of developmental disabilities and behavioral problems, which have been shown to significantly affect human capital accumulation.

\section{Data}

Data for this study come from the 1997, 2002-3, and 2007 waves of the Child Development Supplement of the Panel Study of Income Dynamics (PSID-CDS) and the 2005, 2007, 2009, and 2011 waves of the CDS Youth's Transition into Adulthood (PSID-TA). The PSID is a US based, longitudinal, nationally representative study of individuals and their families that has been ongoing since 1968. The PSID main files include extensive data on socioeconomic variables as well as detailed information on family structure, fertility, health, and a wide range of other topics. The PSID-CDS supplements the information available in the PSID main files by obtaining additional cognitive, behavioral, and health data on PSID children including assessments of behavioral outcomes, and parent reports of diagnosed child health conditions.

In 1997, the first wave of the CDS (CDS-I) interviewed 2,394 families on 3,563 children aged twelve and under, and these children were re-interviewed in 2002-3 (CDS-II) and 2007 (CDS-III) if they were eighteen or younger at the time of interview. The analytic sample used in this paper includes children from the CDS-I, II and III who were born between 1985 and 1997. Upon turning age 18, these children have been followed in the PSID-TA since 2005 . ${ }^{*}$ The data collected on the CDS young adults aged 18 and older include education, work, health, and family relationships among others.

We restrict our samples to children whose primary caregiver is the biological mother, and the head or wife of PSID households, so that we could utilize information on family characteristics from the PSID main files. ${ }^{*}$ Since each survey was administered to up to a maximum of two children in each family, we construct a CDS sample of about 700 sibling

\footnotetext{
*Among the CDS-I children in 1997, 2,358 children are eligible in the TA-2011. The response rate is $81.9 \%$ as 1,907 interviews were completed in TA-2011. For further discussion on attrition, see PSID Transition into Adulthood Study User Guide, 2005-11 (http://psidonline.isr.umich.edu/Guide/documents.aspx).

*We further exclude children whose birth weight is reported to be over $6 \mathrm{~kg}$, as well as siblings whose race differs from each other $(0.22 \%$ of the children in the entire sample).
} 
pairs without missing values for any of the variables used in the study. The summary statistics in Table 1 show that the sibling sample is very comparable in child and family characteristics to the full CDS sample. When we examine educational attainment as an outcome, we draw on information on high-school graduation and college enrollment (which is only available for CDS children who have entered adulthood and continued into the PSIDTA survey) by linking the CDS sample to the PSID-TA files. This TA sample is aged 18 to 28 years old at the time of the interview and it includes fewer than 400 sibling pairs who do not have missing values for any of the variables used in the study.

\subsection{Fetal growth rate}

The PSID-CDS contains information on children's birth weights along with gestational ages, both of which are reported by the primary caregiver. In the literature, alternative measures of fetal growth have been used including birth weight, low birth weight, preterm birth, and the fetal growth rate, all of which reflect the fetal environment in general. Conceptually, low birth weight can result from a fetus growing slowly given a gestational period (small-forgestation) or because a child is born prematurely (preterm birth). While slow fetal growth is caused primarily by poor net nutritional intake in utero, the causes of preterm birth are not well-understood (Slattery and Morrison, 2002; Goldenberg et al., 2008). To distinguish between the contributions of each of these factors, we include in the models both the fetal growth rate and a set of indicators for gestational age. This attempt to separate effects of slow fetal growth from effects of premature birth may be useful since some previous literature suggests that fetal malnutrition is a primary cause of neurological impairment among low birth weight infants (Morgane et al., 1993).*

The fetal growth rate is defined as birth weight in kilograms divided by gestational age in weeks (Behrman et al., 2004). ${ }^{\dagger}$ We use the log of the fetal growth rate which provides a better fit than the fetal growth rate. Preterm birth is measured by a set of binary indicators for gestational age (less than 32 weeks and 32-37 weeks). $\$$ Although we focus on models which include the measure of the fetal growth rate and indicators of preterm birth, we also present results from models which as an alternative to fetal growth rate use the log of birth weight, low birth weight, and very low birth weight in the appendix tables.

\subsection{Neurobehavioral outcomes}

We examine two kinds of neurobehavioral outcomes, behavior problems and diagnosed developmental disabilities, all of which are reported by the child's mother. In addition, we also obtained estimates for speech impairment, and sensory disabilities (hearing and vision impairment), which are reported in the Appendix. For each developmental disability, we define the outcome measure as a binary indicator which is set equal to one if the caregiver reports that a child has ever been diagnosed with the disability by a physician or other health

\footnotetext{
* Some research also suggests that effects of genetic and prenatal factors on infant health outcomes may vary by gestational length (Conley, Strully \& Bennett, 2006).

$\dagger$ There is a line of research in medical science which focuses on preterm births as a treatment group alternative to a group of low birth weight. See Bhutta et al. (2002).

末Preterm birth is defined as less than 37 weeks of gestational age in the literature. We use 32 and 37 as the cutoffs for gestational age because these cutoffs roughly correspond to the cutoffs for low and very low birth weight in terms of proportions in the sample (table $1)$.
} 
professional during any of the CDS survey waves, and zero otherwise. Table 2 shows that the cumulative risk for each developmental disability increases by survey wave as expected. It also reveals that developmental delay, ADHD, vision difficulty, and speech impairment are fairly common. This is consistent with findings from a larger U.S. survey (Boyle et al. 2011).

Outcome measures based on diagnoses may be more objective than parental reports, but they have at least two potential limitations. First, there can be a selection into diagnosis due to access to healthcare or awareness of caregivers. Second, ADHD is often viewed in the medical literature as a continuum rather than a disorder with a cutoff (Levy et al., 1997). To overcome these limitations, we also consider the Behavior Problems Index (BPI), which is constructed based on caregiver reports of behavior problems. We consider the BPI as an alternative measure of neurobehavioral outcomes; it has often been used in the literature (Currie and Stabile 2006, 2009).

The BPI is an assessment of 28 problem behaviors such as sudden mood changes, anxiousness, and meanness towards others. Responses of primary caregiver (biological mother in our context) to whether each of 28 problem behaviors was often, sometimes, or never true of the child in question are recoded and summed to generate the BPI total score (Peterson and Zill 1986). The BPI total score is obtained based on dichotomous recoding (never $=0$; often or sometimes $=1$ ). Higher scores imply a greater level of behavior problems. Alternatively, several subscales can be created based on the subsets of those responses. We consider the hyperactive, antisocial, oppositional, depressed, and peer problems subscales. Each score is standardized to have a mean of 100 and a standard deviation of 15 where age and sex are adjusted in reference to a national survey. We use standardized scores both because the raw scores tend to be higher among boys than among girls and because the children in our sample cover a rather wide range of ages (4 to 15).

These problem behavior scales have often been used in the literature (Currie and Stabile 2006, 2009; Fletcher and Wolfe 2008) as they have certain advantages over other objective measures such as ever-diagnosed developmental disabilities. First, selection bias in diagnosis does not arise since all children aged 4 and older are assessed by their mothers. Second, since the BPI provides a continuous measure of problem behaviors, it can address the concern about using a binary indicator for ADHD, which necessarily imposes an arbitrary threshold. One potential problem is that the assessment may be subjective, but any reporting bias that is mother-specific will be removed in our preferred mother fixed effects (MFE) model. Table 3 shows that the BPI scores are noticeably higher among children having a diagnosed disability than those without it. For example, the hyperactive sub-scale score is about one standard deviation higher among children who have ever been diagnosed of ADHD compared to children who have never been diagnosed with ADHD.*

\footnotetext{
* See data appendix for details.

* Similarly, we find that the anxious/depressed score is about one standard deviation higher among children who have ever been diagnosed with severe emotional problems than those who have never been diagnosed with severe emotional problems.
} 


\subsection{Other covariates}

To obtain measures for the socioeconomic environment of children which may be correlated with both prenatal environment and neurobehavioral outcomes, we link the children in the CDS files to their biological mothers in the PSID main files. The child-specific controls included in the models are: child's sex, birth order, indicators for mother's age (less than 20, more than 35, or in-between) and mothers' marital status at child's birth, cigarette excise taxes at child's birth and state, and measures of the cognitive stimulation and emotional support in the home (HOME - cognitive and emotional scales). These regressors are intended to measure parental inputs (time, energy, and materials) related to child development as well as child's perinatal environment. ${ }^{\dagger}$ The mother-specific controls include indicators for race/ethnicity, mother's years of schooling, and permanent family income. We measure permanent family income by taking the average of family income (measured in 1997 constant dollars) from all available years in the PSID main files.

\subsection{Educational attainment in young adulthood}

Our main interest is in the association between the fetal growth rate and neurobehavioral outcomes in childhood. We also, however, consider whether the neurobehavioral outcomes themselves are associated with educational attainment during young adulthood to gauge whether there is evidence that neurobehavioral outcomes may be a mechanism linking the fetal growth rate to subsequent human capital outcomes. We use two binary indicators of educational attainment, whether the respondent completed high school and whether the respondent ever entered college.

We define a binary indicator for high school completion as one if the respondent graduated from high school or got GED and zero otherwise. Also, we define a binary indicator for college enrollment as one if the respondent has ever attended any type of college and zero otherwise given that the respondent completed high school (high school dropouts, about 6\% of our sibling sample, are excluded). To examine the partial effect of neurobehavioral problems on educational attainment, we further control for cognitive skills in a specification. We use as a measure for cognitive skills an age-standardized score for Applied Problems, a math score, which is shown to be a strong predictor of subsequent educational attainment in the literature (Murnane et al. 1995 for example). Since the assessment of the academic achievement and problem behaviors was administered repeatedly, we take the average score before age 15 .

\footnotetext{
$\dagger$ Apart from fetal malnutrition, Wehby et al. (2011) show that maternal smoking during pregnancy can impair child neurodevelopment. This finding implies that failure to control for prenatal smoking may result in omitted variable bias since prenatal smoking is associated with low birth weight and preterm delivery as well. Unfortunately, information on maternal smoking at pregnancy is not available in the PSID-CDS because information on smoking status of head and wife was collected in the years 1986 and after 1999 while most of the children in our sample are born during the periods 1985-1997. In all models, however, we control for cigarette excise taxes at child's year of birth and state, which has been shown to be effective means of lowering the prevalence of smoking among pregnant women in the literature (Evans and Ringel 1999; Colman and Grossman 2002; Lien and Evans 2005). Furthermore, to the extent that nicotine is strongly addictive, our MFE estimation will address concern for omitted prenatal smoking since the average birth spacing in our sibling sample is 3.2 years. The information on state cigarette excise taxes comes from Tax burden on tobacco, historical compilation, volume 46, 2011. http://nocigtax.com/upload/file/158/ Tax_Burden_on_Tobacco_vol._46_FY2011.pdf.
} 


\section{Empirical Method}

\subsection{Mother fixed effects (MFE)}

We estimate the following model:

$$
\text { Outcome }_{i j}=X_{i j} \beta+\gamma F G R_{i j}+m_{i}+u_{i j}
$$

where Outcome $_{i j}$ denotes a neurobehavioral outcome of child $j$ of mother $i, X_{i j}$ a set of controls for child and family characteristics, $F G R_{i j}$ the $\log$ of the fetal growth rate, $G E S T_{i j}$ the set of indicators for gestational age, $m_{i}$ the mother fixed effects, and $u_{i j}$ the error term. When we consider ever-diagnosed developmental disabilities, Outcome $e_{i j}$ is a binary indicator and the equation (1) can be seen as a linear probability model. When we consider behavioral problems, Outcome $i j$ is a continuous variable. The coefficient $\gamma$ captures the effect of the fetal growth rate on developmental outcomes in childhood.

Before estimating Equation 1, we start with a baseline OLS specification which includes an extensive set of observed mother and child characteristics but excludes the mother fixed effects $m_{i}$. Even when we control for an extensive set of observed factors, however, there may be unobserved factors such as family background, mother's risk preferences, and genetic inheritance that are correlated with both birth weight and neurobehavioral outcomes in childhood. In this case, OLS estimates will not be consistent. Thus, we estimate equation (1) using the MFE estimation. This approach allows for maternal heterogeneity to be correlated with any of the regressors including the fetal growth rate. Since we restrict our sample to biological mothers, MFE estimation will partially address the concern for unobserved genetic factors as well. Moreover, MFE estimation can minimize the reporting bias arising from the use of mother-reported outcome measure (the BPI) as well as the recall bias regarding birth weight and gestational age. For all models, we make inferences based on robust standard errors that are clustered at the mother level to account for possible correlation within siblings. ${ }^{*}$ In an alternative specification of the MFE model, we allow for the effects of the fetal growth rate to differ among boys and girls by including interaction terms between the fetal growth rate and a binary indicator for sex. ${ }^{\dagger}$

When we examine the effects of neurobehavioral outcomes on educational attainment, we use the same general approach except Outcome $_{i j}$ is a binary measure of whether the child completed high school (or a binary indicator of college entry), and $F G R_{i j}$ is replaced by a neurobehavioral outcome. These models include the same covariates as the models described above, with the addition of year of birth to account for the fact that the older cohorts had higher chance of high school completion and college enrollment ${ }^{\ddagger}$, and a math achievement test score to capture cognitive ability.

\footnotetext{
* Singleton siblings share a fourth of the genetic composition on the average while dizygotic twins share a half of the genetic composition.

†Separate analysis by sex may be ideal, but this would decrease the sample size by three quarters as any random sibling sample will consist of male-male, male-female, female-male, and female-female pairs with equal proportions.

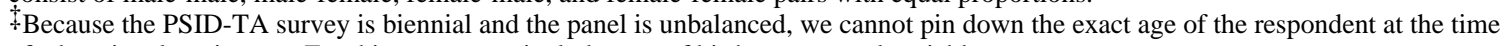
of educational attainment. For this reason, we include year of birth as a control variable.
} 


\section{Results}

In Table 4, we present the estimated effect of the fetal growth rate on ever-diagnosed developmental disabilities for the sibling sample. The first two columns for each developmental disability show the estimated coefficient for the fetal growth rate and gestational ages from the OLS and MFE models. In the OLS model, we find that log of the fetal growth rate is negatively associated with a lifetime diagnosis of developmental delay, but associations with ADHD diagnosis are not statistically significant. In our preferred MFE model, we find that log of the fetal growth rate is negatively associated with a lifetime diagnosis of developmental delay (Table 4), and also with lifetime diagnosis of speech impairment (Appendix Table 3). A ten percent increase in the fetal growth rate translates into a 1.9 percentage point decrease in lifetime risk of developmental delay, (see figure 1). We also find that very preterm birth (less than 32 weeks in gestational age) leads to a 35 percentage point increase in the risk for serious vision difficulty compared to term birth (37 or more in gestational age) (Appendix Table 3). We find some evidence that log of the fetal growth rate is positively associated with serious hearing impairment, but the estimates are marginally significant and the fit is exceptionally poor. ${ }^{*}$

Notice that the MFE estimates tend to be larger in size than the OLS estimates. One possible explanation for this pattern is the mother-specific measurement error for birth weight and gestational age. To the extent that birth weight and gestational age of children are recalled with imprecision depending on the mother, the OLS estimates will be subject to attenuation bias whereas this mother-specific measure error will be swept out in the MFE model, yielding consistent estimates. A similar pattern has been reported in Johnson and Schoeni (2011) and Fletcher (2011) who find their MFE estimates of birth weight greater than the OLS estimates.

The third column for each outcome measure shows the estimates obtained from the model that includes interaction terms between the fetal growth rate and the binary indicators for males and females. This specification allows for the effect of the fetal growth rate to differ by sex. The estimates for interaction terms show that the estimated negative effect of fetal growth rate on developmental delay differs little between boys and girls as the $F$ statistic is shown close to zero. In contrast, the estimated negative effect of fetal growth rate on ADHD in column (5) appears to be driven by boys. Although the estimates are not statistically significant and the $p$-value is rather high, we will find a similar pattern for hyperactive scores in table 5 as the estimated effect of fetal growth rate is statistically significant only among boys.

Table 5 presents the estimated effects of the fetal growth rate on behavioral problems measured by the BPI. We find that the log of the fetal growth rate is negatively associated with the BPI total score. This seems to be driven by disruptive behaviors represented by

\footnotetext{
*In Appendix Table 1, we find that many of the alternative measures of fetal growth have statistically significant effects on developmental delay and the signs are as expected. In contrast, the estimated effects of the alternative measures of fetal growth on ADHD are statistically significant only in one case -- the very low birth weight dummies. In Appendix Table 2, we find that the alternative measures of fetal growth have statistically significant effects on the BPI total and antisocial scores. The estimated effects on other scores are statistically insignificant although the signs are generally as expected.
} 
antisocial, oppositional/defiant, and hyperactive scores. The preferred MFE estimates show that a ten percent increase in the fetal growth rate translates into a 0.04 standard deviation decrease in the BPI total score. ${ }^{*}$ The third columns for each outcome which contain interaction with male/female indicators suggest that the effect of the fetal growth rate on disruptive behaviors is more pronounced among boys than among girls. Among boys, a ten percent increase in the fetal growth rate translates into a 0.07 standard deviation decrease in the antisocial behavior score, a 0.03 standard deviation decrease in the oppositional behavior score, and a 0.05 standard deviation decrease in the hyperactive behavior score. ${ }^{*}$

Table 6 shows the effects of neurobehavioral problems measured before age 15 on educational attainment in young adulthood. In columns (1) and (7) of panel A, we find that higher total BPI score and diagnosed ADHD significantly lower the chance of completing high school. A one standard deviation increase in the total BPI score decreases the chance of high school completion by 3 percentage points, while diagnosed ADHD decreases the chance by 8.5 percentage points. ${ }^{\dagger}$ However, these effects are attenuated as we further control for math scores in childhood, which are a significant predictor of high school completion in all models.

Columns (1) and (3) of panel B show that the total BPI score and the antisocial score have negative and significant effects on college enrollment. A one standard deviation increase in scores lowers the chance of college enrollment by 6 percentage points and 7.5 percentage points respectively. Furthermore, these second-stage effects remain robust after controlling for cognitive skills measured by math scores in childhood, which are estimated to have smaller effects on college enrollment in young adulthood. However, it should be noted that the sample size in these regressions is relatively small, and as we focus on the first-stage effect, the potential dynamic interaction between cognitive and non-cognitive skills is not considered (Cunha and Heckman 2008).

\section{Conclusion}

The effect of birth weight on later outcomes has drawn much attention across the social science disciplines since it may constitute a mechanism for the inter-generational transmission of poverty, given that disadvantaged families have a higher prevalence of low birth weight children. Prior research, however, has focused on cognitive ability as a mediating factor in the association between birth weight and later outcomes, while the recent literature emphasizes that the abilities that are useful in education and labor market are multifaceted (Bowles et al., 2001; Carneiro et al., 2007; Heckman, 2008). In this context, we examine the effect of birth weight on noncognitive outcomes in childhood, as measured by a host of behavioral, developmental, and sensory problems.

\footnotetext{
* The partial change in score in response to a ten percent change in the fetal growth rate can be obtained from $0.1 * 6.35 / 15=0.0423$ as the standard deviation is 15 .

*We include F-statistics and p-values for testing the equality of the coefficients on the two interaction terms (FGR*male and FGR*female) at the bottom of the Tables 4-5 and Appendix Table 3. Among the disruptive behaviors (hyperactive, antisocial, oppositional/defiant), we could reject the null hypothesis of equality for oppositional outcomes at the 0.10 level, but not for the antisocial and hyperactive score.

${ }^{\dagger}$ Because all the scores are standardized to have mean 15, a one standard deviation increase in the total BPI score translates into a 3 percentage point decrease in the probability of high school completion.
} 
In this paper, we find that, after controlling for mother fixed effects, the fetal growth rate is an important predictor for the risk of developmental disabilities such as developmental delay, and speech impairment, which in turn may inhibit children from developing cognitive skills and accumulating human capital. In addition, we find some evidence that the fetal growth rate is associated with mother-reported disruptive behaviors including antisocial, oppositional, and hyperactive behaviors, after controlling for mother fixed effects. This is consistent with the results in Datta Gupta et al. (which do not include mother fixed effects) in that birth weight is negatively associated with increased symptoms of ADHD and conduct disorder during childhood among males. We also find that childhood behavior problems, especially antisocial behavior problems, have negative and significant effects on college enrollment, although our sample sizes are small when we examine this outcome.

Our findings suggest that developmental disabilities play a role in explaining the welldocumented association between birth weight and later outcomes. Given the growing recognition of the importance of the prenatal and early childhood stages of life for subsequent human capital outcomes (Doyle et al., 2009), our results suggest that public policy interventions that can improve birth outcomes may have long-term benefits in terms of improved developmental outcomes in childhood and beyond. We note, however, that our findings for the speech impairment outcome, and behavior problems outcomes, are not statistically significant in the OLS specifications. Moreover, the overall pattern of findings indicates that the effects of the fetal growth rate on neurobehavioral outcomes are small in magnitude. For these reasons, we interpret these results with caution.

The data set used in the analysis imposes several limitations for our study. First, potential sex differences reported in the literature are not well addressed in the regressions for developmental disabilities. Using brother siblings or sister siblings leaves us little statistical power due to the small size of the subsamples. Second, the potential dynamic effect of the fetal growth rate or age-specific effect cannot be studied because siblings are assessed at different ages for a given survey year. This limitation can be overcome with a panel data set for twins of similar birth cohorts. Finally, information on maternal health behaviors during pregnancy such as smoking and drinking is very limited in the data set. To the extent that the role of these health behaviors is an important factor that determines the fetal growth rate, it should be interpreted as a marker for fetal environment rather than cumulative net nutritional intake in utero.

\section{Data Appendix - Items for BPI subscales}

\begin{tabular}{|c|c|c|c|c|c|c|}
\hline$\#$ & Questions & Anxious/depressed & Oppositional & Hyperactive & Antisocial & $\begin{array}{l}\text { Peer } \\
\text { problem }\end{array}$ \\
\hline 1 & $\begin{array}{l}\text { (He/She) has sudden changes } \\
\text { in mood or feeling }\end{array}$ & $\mathrm{O}$ & & & & \\
\hline 2 & $\begin{array}{l}\text { (He/She) feels or complains } \\
\text { that no one loves him/her }\end{array}$ & $\mathrm{O}$ & & & & \\
\hline 3 & $\begin{array}{l}\text { (He/She) is too fearful or } \\
\text { anxious }\end{array}$ & $\mathrm{O}$ & & & & \\
\hline
\end{tabular}




\begin{tabular}{|c|c|c|c|c|c|c|}
\hline$\#$ & Questions & Anxious/depressed & Oppositional & Hyperactive & Antisocial & $\begin{array}{l}\text { Peer } \\
\text { problem }\end{array}$ \\
\hline 4 & $\begin{array}{l}\text { (He/She) feels worthless or } \\
\text { inferior }\end{array}$ & $\mathrm{O}$ & & & & \\
\hline 5 & $\begin{array}{l}\text { (He/She) is unhappy, sad or } \\
\text { depressed }\end{array}$ & $\mathrm{O}$ & & & & \\
\hline 6 & $\begin{array}{l}\text { (He/She) is rather high strung, } \\
\text { tense and nervous }\end{array}$ & & $\mathrm{O}$ & & & \\
\hline 7 & (He/She) argues too much & & $\mathrm{O}$ & & & \\
\hline 8 & (He/She) is disobedient & & $\mathrm{O}$ & & & \\
\hline 9 & $\begin{array}{l}\text { (He/She) stubborn, sullen, or } \\
\text { irritable }\end{array}$ & & $\mathrm{O}$ & & & \\
\hline 10 & $\begin{array}{l}\text { (He/She) has a very strong } \\
\text { temper and loses it easily }\end{array}$ & & $\mathrm{O}$ & & & \\
\hline 11 & $\begin{array}{l}\text { (He/She) has difficulty } \\
\text { concentrating, cannot pay } \\
\text { attention for long }\end{array}$ & & & $\mathrm{O}$ & & \\
\hline 12 & $\begin{array}{l}\text { (He/She) is easily confused, } \\
\text { seems to be in a fog }\end{array}$ & & & $\mathrm{O}$ & & \\
\hline 13 & $\begin{array}{l}\text { (He/She) is impulsive, or acts } \\
\text { without thinking }\end{array}$ & & & $\mathrm{O}$ & & \\
\hline 14 & $\begin{array}{l}\text { (He/She) has a lot of difficulty } \\
\text { off certain thoughts }\end{array}$ & tting (his/her) mind & & $\mathrm{O}$ & & \\
\hline 15 & $\begin{array}{l}\text { (He/She) is restless or overly } \\
\text { active, cannot sit still }\end{array}$ & & & $\mathrm{O}$ & & \\
\hline 16 & (He/She) chats or tells lies & & & & $\mathrm{O}$ & \\
\hline 17 & $\begin{array}{l}\text { (He/She) bullies or is cruel or } \\
\text { mean to others }\end{array}$ & & & & $\mathrm{O}$ & \\
\hline 18 & $\begin{array}{l}\text { (He/She) does not seem to feel } \\
\text { sorry after misbehaves }\end{array}$ & & & & $\mathrm{O}$ & \\
\hline 19 & $\begin{array}{l}\text { (He/She) breaks things on purpe } \\
\text { own or another's things }\end{array}$ & or deliberately destro & ys (his/her) & & $\mathrm{O}$ & \\
\hline 20 & $\begin{array}{l}\text { (He/She) is disobedient at } \\
\text { school }\end{array}$ & & & & $\mathrm{O}$ & \\
\hline 21 & $\begin{array}{l}\text { (He/She) has trouble getting } \\
\text { along with teachers }\end{array}$ & & & & $\mathrm{O}$ & \\
\hline 22 & $\begin{array}{l}\text { (He/She) has trouble getting } \\
\text { along with other people (his/ } \\
\text { her) age }\end{array}$ & & & & & $\mathrm{O}$ \\
\hline 23 & $\begin{array}{l}\text { (He/She) is not liked by other } \\
\text { people (his/her) age }\end{array}$ & & & & & $\mathrm{O}$ \\
\hline 24 & $\begin{array}{l}\text { (He/She) is withdrawn, does } \\
\text { not get involved with others }\end{array}$ & & & & & $\mathrm{O}$ \\
\hline 25 & (He/She) clings to adults & & & & & \\
\hline 26 & (He/She) cries too much & & & & & \\
\hline 27 & (He/She) demands attention & & & & & \\
\hline 28 & $\begin{array}{l}\text { (He/She) is too dependent on } \\
\text { others }\end{array}$ & & & & & \\
\hline
\end{tabular}

The table above contains 28 questionnaires asked to all primary caregivers (biological mothers) regarding to behavior problems of their children. Among these, five questions 
pertain to anxious/depressed, oppositional, and hyperactive subscales, six questions to the antisocial subscale, and three to the peer problem subscale. ${ }^{*}$ Mother's responses to whether each of 28 problem behaviors was often, sometimes, or never true of the child in question are recoded (never $=0$; often or sometimes $=1$ ) and summed to generate the Behavior Problems Index (BPI) total score, or scores of subscales. We convert these raw scores to the standardized scores having mean 100 and standard deviation 15, where age and sex are adjusted based on the national distribution. Since the PSID does not provide standardized scores, we use the norming table designed for NLSY79 Child Surveys, as all the questions asked are identical. ${ }^{\dagger}$

\section{References}

Anderson P, Doyle LW, et al. Neurobehavioral outcomes of school-age children born extremely low birth weight or very preterm in the 1990s. Journal of the American Medical Association. 2003; 289:3264-3272. [PubMed: 12824207]

Behrman JR, Rosenzweig MR. Returns to birth weight. Review of Economics and Statistics. 2004; 86:586-601.

Bhutta AT, Cleves MA, Casey PH, Cradock MM, Anand K. Cognitive and behavioral outcomes of school aged children who were born preterm. Journal of the American Medical Association. 2002; 288:728-737. [PubMed: 12169077]

Black SE, Devereux PJ, Salvanes KG. From the cradle to the labor market? the effect of birth weight on adult outcomes. Quarterly Journal of Economics. 2007; 122:409-439.

Boardman JD, Powers DA, Padilla YC, Hummer RA. Low birth weight, social factors, and developmental outcomes among children in the United States. Demography. 2002; 39:353-368. [PubMed: 12048956]

Bowles S, Gintis H, Osborne M. The determinants of earnings: A behavioral approach. Journal of Economic Literature. 2001; 39:1137-1176.

Boyle CA, et al. Trends in the prevalence of developmental disabilities in us children, 1997-2008. Pediatrics. 2011; 127:1034-1042. [PubMed: 21606152]

Boulet SL, Schieve LA, Boyle CA. Birth weight and health and developmental outcomes in US children, 1997-2005. Maternal and Child Health Journal. 2011; 15:836-844. [PubMed: 19902344]

Carneiro, P.; Crawford, C.; Goodman, A. The impact of early cognitive and non-cognitive skills on later outcomes. Center for Economics of Education; 2007. Discussion Paper 92

Chaloupka, FJ.; Warner, KE. The Economics of Smoking. In: Anthony, JC.; Newhouse, JP., editors. Handbook of Health Economics. Vol. 1B. Vol. 2000. Elsevier Science, North-Holland; Amsterdam: 2000. p. 1539-1627.

Colman G, Grossman M. The effect of cigarette excise taxes on smoking before, during and after pregnancy. Journal of Health Economics. 2003; 22:1053-1072. [PubMed: 14604560]

Conley D, Strully KW, Bennett NG. Twin differences in birth weight: The effects of genotype and prenatal environment on neonatal and post-neonatal mortality. Economics \& Human Biology. 2006; 4:151-183. [PubMed: 16439189]

Cook CJ, Fletcher JM. Interactive effects of in utero nutrition and genetic inheritance on cognition: New evidence using sibling comparisons. Economics \& Human Biology. 2014; 13:144-154. [PubMed: 24172871]

Corman H, Chaikind S. The effect of low birthweight on the school performance and behavior of school-aged children. Economics of Education Review. 1998; 17:307-316.

Cunha F, Heckman J. Formulating, identifying and estimating the technology of cognitive and noncognitive skill formation. Journal of Human Resources. 43:738-782.

\footnotetext{
*Based on the last four items in the table, one can create the dependent subscale, which was not considered in the analysis.

† See Appendix D-2 in the NLSY79 Child \& Young Adult Data Users Guide (http://www.nlsinfo.org/pub/usersvc/Child-Young-Adult/ 2006ChildYA-DataUsersGuide.pdf). The norming table for US children is created based on the 1981 national health interview survey.
} 
Currie J, Stabile M. Child mental health and human capital accumulation: the case of adhd. Journal of Health Economics. 2006; 25:1094-1118. [PubMed: 16730082]

Currie, J.; Stabile, M. Mental health in childhood and human capital. In: Gruber, J., editor. The Problems of Disadvantaged Youth: An Economic Perspective. University of Chicago; Chicago: 2009.

Datta Gupta N, Deding M, Lausten M. The effect of low birth weight on height, weight and behavioral outcomes in the medium-run. Economics \& Human Biology. 2013; 11:42-55. [PubMed: 21737364]

Doyle O, Harmon CP, Heckman JJ, Tremblay RE. Investing in early human development: Timing and economic efficiency. Economics and Human Biology. 2009; 7:1-6. [PubMed: 19213617]

Evans WN, Ringel JS. Can higher cigarette taxes improve birth outcomes? Journal of Public Economics. 1999; 72:135-154.

Figlio, DN.; Guryan, J.; Karbownik, K.; Roth, J. The effects of poor neonatal health on children's cognitive development. 2013. NBER Working Paper No. 18846

Fletcher, Jason M. The medium term schooling and health effects of low birth weight: Evidence from siblings. Economics of Education Review. 2011; 30:517-527.

Goldenberg RL, Culhane JF, Iams JD, Romero R. Epidemiology and causes of preterm birth. The Lancet. 2008; 371:75-84.

Groen-Blokhuis MM, Middeldorp CM, van Beijsterveldt CE, Boomsma DI. Evidence for a causal association of low birth weight and attention problems. Journal of the American Academy of Child \& Adolescent Psychiatry. 2011; 50:1247-1254. [PubMed: 22115145]

Heckman JJ. Schools, skills, and synapses. Economic Inquiry. 2008; 46:289-324. [PubMed: 20119503]

Hoy EA, Sykes DH, Bill JM, Halliday HL, McClure BG, Reid MC. The social competence of verylow birth weight children: teacher, peer, and self-perceptions. Journal of Abnormal Child Psychology. 1992; 20:123-150. [PubMed: 1593023]

Hultman CM, Torrång A, Tuvblad C, Cnattingius S, Larsson J-O, Lichtenstein P. Birth weight and attention-deficit/hyperactivity symptoms in childhood and early adolescence: a prospective Swedish twin study. Journal of the American Academy of Child \& Adolescent Psychiatry. 2007; 46:370-377. [PubMed: 17314723]

Johnson RC, Schoeni RF. The influence of early life events on human capital, health status, and labor market outcomes over the life course. The B. E. Journal of Economic Analysis \& Policy. 2007; 11(3) Article 1.

Kelly YJ, Nazroo JY, McMunn A, Boreham R, Marmot M. Birth weight and behavioural problems in children: a modifiable effect? International Journal of Epidemiology. 2001; 30:88-94. [PubMed: 11171863]

Levy F, Hay DA, McSTEPHEN M, Wood C, Waldman I. Attention-deficit hyperactivity disorder: a category or a continuum? genetic analysis of a large-scale twin study. Journal of the American Academy of Child \& Adolescent Psychiatry. 1997; 36:737-744. [PubMed: 9183127]

Lien DS, Evans WN. Estimating the impact of large cigarette tax hikes. Journal of Human Resources. 2005; 40:373-392.

Lindquist E, Westman R. The labor market returns to cognitive and noncognitive ability: Evidence from the Swedish enlistment. American Economic Journal: Applied Economics. 2011; 3:101-128.

Matte TD, Bresnahan M, Begg MD, Susser E. Influence of variation in birth weight within normal range and within sibships on IQ at age 7 years: cohort study. British Medical Journal. 2001; 323:310-314. [PubMed: 11498487]

McCormick MC, Brooks-Gunn J, Workman-Daniels K, Turner J, Peckham GJ. The health and developmental status of very low-birth-weight children at school age. Journal of the American Medical Association. 1992; 267:2204-2208. [PubMed: 1556798]

Morgane PJ, Austin-LaFrance R, Bronzino J, Tonkiss J, Diaz-Cintra S, Cintra L, Kemper T, Galler JR. Prenatal malnutrition and development of the brain. Neuroscience \& Biobehavioral Reviews. 1993; 17:91-128. [PubMed: 8455820]

Murnane R, Willett JB, Levy F. The growing importance of cognitive skills in the wage determination. The Review of Economics and Statistics. 1995; 77:251-266. 
Nelson, K. The placenta and neurological outcome in the child. In: Baker, P.; Sibley, C., editors. The Placenta and Neurodisability. Cambridge University Press; 2006.

Oreopoulos P, Stabile M, Walld R, Roos LL. Short-, medium-, and long-term consequences of poor infant health: an analysis using siblings and twins. Journal of Human Resources. 2008; 43:88-138.

Peterson JL, Zill N. Marital disruption, parent-child relationship, and behavior problems in children. Journal of Marriage and Family. 1986; 48:295-307.

Royer H. Separated at girth: US twin estimates of the effects of birth weight. American Economic Journal: Applied Economics. 2009; 1:49-85.

Schendel DE, Stockbauer JW, Hoffman HJ, Herman AA, Berg CJ, Schramm WF. Relation between very low birth weight and developmental delay among preschool children without disabilities. American Journal of Epidemiology. 1997; 146:740-749. [PubMed: 9366622]

Slattery MM, Morrison JJ. Preterm delivery. The Lancet. 2002; 360:1489-1497.

Strauss RS. Adult functional outcome of those born small for gestational age: twenty-six year followup of the 1970 british birth cohort. Journal of the American Medical Association. 2000; 283(5): 625-632. [PubMed: 10665702]

Torche F, Echevarría G. The effect of birth weight on childhood cognitive development in a middleincome country. International journal of epidemiology. 2011; 40:1008-1018. [PubMed: 21362701]

Wehby GL, Kaitlin P, McCarthy AM, Castilla E, Murray JC. The impact of maternal smoking during pregnancy on early child neurodevelopment. Journal of Human Capital. 2011; 5:207-254. [PubMed: 22272363]

Wiles NJ, Peters TJ, Heron J, Gunnell D, Emond A, Lewis G, et al. Fetal growth and childhood behavioral problems: results from the ALSPAC cohort. American Journal of Epidemiology. 2006; 163:829-837. [PubMed: 16524956] 


\section{Highlights}

- Although there is evidence from prior studies that low birth weight is associated with lower cognitive test scores, the body of research focusing on the effect of birth weight on non-cognitive outcomes, such as neurobehavioral outcomes, is more limited.

- Using national, longitudinal, survey data on children from the US, we find that poor fetal growth is associated with increased risk of lifetime diagnosis of developmental delay and speech impairment.

- We also find that poor fetal growth is associated with an index of behavior problems reported by mothers. In particular, the fetal growth rate is negatively associated with disruptive behaviors such as antisocial, oppositional, and hyperactive behaviors among boys. 
A. Developmental delay
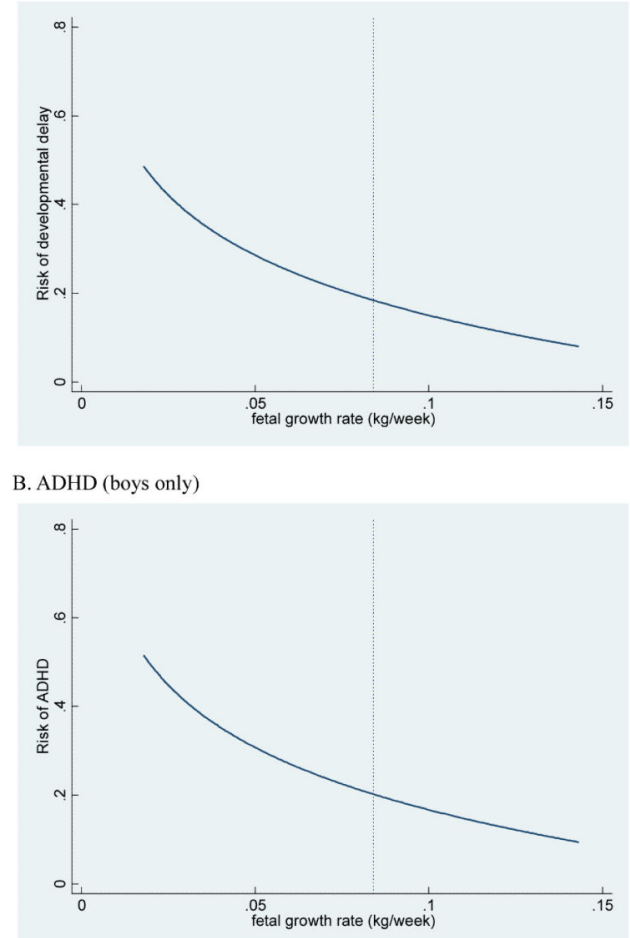

Figure 1.

Estimated Effects of Fetal Growth Rate on Selected Developmental Disabilities

Figure note: The vertical dotted line represents the sample mean of fetal growth rate. The risk curve is created based on the estimated elasticities in table 4. We depict an ADHD figure for boys only because the negative effect of fetal growth rate on ADHD is found only among boys (see table 4 and 5). 


\section{Table 1}

\section{Descriptive Statistics}

\begin{tabular}{|c|c|c|c|c|c|}
\hline \multirow[t]{2}{*}{ Variables } & \multicolumn{2}{|c|}{ Full sample } & \multicolumn{3}{|c|}{ Sibling sample } \\
\hline & $\mathbf{N}$ & Mean & $\mathbf{N}$ & Mean & SD \\
\hline \multicolumn{6}{|l|}{ Neurobehavioral outcomes } \\
\hline \multicolumn{6}{|l|}{ A. Developmental disabilities } \\
\hline ADHD & 2,482 & 0.10 & 1,463 & 0.10 & 0.30 \\
\hline Developmental delay & 2,483 & 0.10 & 1,464 & 0.09 & 0.29 \\
\hline \multicolumn{6}{|c|}{$\begin{array}{l}\text { B. Behavior Problems Index (BPI) - Standardized } \\
\text { score }\end{array}$} \\
\hline Total score & 1,616 & 106.7 & 987 & 106.2 & 15.2 \\
\hline Hyperactive score & 1,758 & 107.7 & 1,063 & 106.5 & 12.7 \\
\hline Antisocial score & 1,746 & 105.9 & 1,059 & 105.6 & 13.1 \\
\hline Oppositional/Defiant score & 1,757 & 105.4 & 1,062 & 105.1 & 11.2 \\
\hline Anxious/Depressed score & 1,757 & 107.2 & 1,063 & 106.5 & 11.4 \\
\hline Peer problem score & 1,698 & 109.1 & 1,032 & 108.4 & 12.5 \\
\hline \multicolumn{6}{|c|}{ C. Behavior Problems Index (BPI) - Raw score } \\
\hline Total score & 1,616 & 12.5 & 987 & 12.1 & 7.1 \\
\hline Hyperactive score & 1,758 & 2.2 & 1,063 & 2.1 & 1.4 \\
\hline Antisocial score & 1,746 & 1.9 & 1,059 & 1.9 & 1.5 \\
\hline Oppositional/Defiant score & 1,757 & 2.6 & 1,062 & 2.5 & 1.4 \\
\hline Anxious/Depressed score & 1,757 & 2.1 & 1,063 & 2.0 & 1.3 \\
\hline Peer problem score & 1,698 & 0.9 & 1,032 & 0.8 & 0.9 \\
\hline \multicolumn{6}{|l|}{ Cognitive outcomes in childhood } \\
\hline Applied Problems (math score) & 1,600 & 15.7 & 776 & 106.1 & 15.45 \\
\hline \multicolumn{6}{|l|}{ Educational outcomes in young adulthood } \\
\hline High school graduation & 1,600 & 0.25 & 776 & 0.94 & 0.23 \\
\hline Enrollment in college & 1,488 & 0.42 & 704 & 0.76 & 0.43 \\
\hline \multicolumn{6}{|l|}{ Measures for fetal growth } \\
\hline Birth weight (kg) & 2,483 & 3.33 & 1,464 & 3.3 & 0.63 \\
\hline Low birth weight $(<2.5 \mathrm{~kg})$ & 2,483 & 0.09 & 1,464 & 0.1 & 0.28 \\
\hline Very low birth weight $(<1.5 \mathrm{~kg})$ & 2,483 & 0.01 & 1,464 & 0.0 & 0.09 \\
\hline Gestational age (weeks) & 2,483 & 39.49 & 1,464 & 39.5 & 2.18 \\
\hline Preterm birth (<37 weeks) & 2,483 & 0.08 & 1,464 & 0.1 & 0.28 \\
\hline Preterm birth (<32 weeks) & 2,483 & 0.01 & 1,464 & 0.0 & 0.10 \\
\hline Fetal growth rate (kg/weeks) & 2,483 & 0.08 & 1,464 & 0.08 & 0.01 \\
\hline \multicolumn{6}{|l|}{ Child and maternal characteristics } \\
\hline Female & 2,483 & 0.49 & 1,464 & 0.49 & 0.50 \\
\hline White & 2,483 & 0.52 & 1,464 & 0.57 & 0.50 \\
\hline African American & 2,483 & 0.43 & 1,464 & 0.39 & 0.49 \\
\hline Latino & 2,483 & 0.02 & 1,464 & 0.01 & 0.11 \\
\hline Other & 2,483 & 0.04 & 1,464 & 0.03 & 0.18 \\
\hline Mother single at child birth & 2,483 & 0.36 & 1,464 & 0.32 & 0.47 \\
\hline
\end{tabular}

Econ Hum Biol. Author manuscript; available in PMC 2015 December 01. 


\begin{tabular}{lrrrrrrr}
\hline \multirow{2}{*}{ Variables } & \multicolumn{2}{c}{ Full sample } & & \multicolumn{3}{c}{ Sibling sample } \\
& & N & Mean & & N & Mean & SD \\
\hline Mother's age at child birth & 2,483 & 26.72 & & 1,464 & 26.49 & 5.45 \\
Birth order & 2,483 & 1.90 & 1,464 & 2.04 & 1.01 \\
Home scale - Cognitive & 2,483 & 9.57 & 1,464 & 9.78 & 2.31 \\
Home scale - Emotional & 2,483 & 9.19 & 1,464 & 9.33 & 2.24 \\
Maternal education & 2,483 & 12.92 & 1,464 & 12.98 & 2.13 \\
Log of lifetime family income & 2,483 & 10.56 & 1,464 & 10.57 & 0.71 \\
Cigarette excise tax at child birth & 2,483 & 25.54 & 1,464 & 25.66 & 13.92 \\
\hline
\end{tabular}

Note: Entries are from 1997, 2002-3, 2007 waves of the PSID-CDS and 2005, 2007, 2009, 2011 waves of the PSID-TA. N denotes the number of children in the sample. All the observations are excluded that contain missing information on infant health and child, maternal characteristics. Developmental disabilities are binary indicators that equal to one if child was ever diagnosed of the disability during all survey waves. The child average of the BPI and the Applied Problems scores over all survey waves before age 15 was used for tabulation as the BPI and Applied Problems scores are assessed multiple (at most three) times for each child. Lifetime family income and cigarette excise taxes are measured in 1997 constant dollars and cents per pack. 


\section{Table 2}

Ever-diagnosed Disabilities by Survey Wave

\begin{tabular}{lrc}
\hline Ever-diagnosed disabilities & $\begin{array}{c}\text { Developmental } \\
\text { delay }\end{array}$ & ADHD \\
\hline Wave 1 (1997) & $2.95 \%$ & $2.17 \%$ \\
Wave 2 (2002-3) & $5.81 \%$ & $6.07 \%$ \\
Wave 3 (2007) & $6.94 \%$ & $8.33 \%$ \\
\hline N & 1153 & 1153 \\
Age of first lifetime diagnosis & 11.5 & 11.8 \\
\hline
\end{tabular}

Note: 1997, 2002-3, 2007 waves of the PSID-CDS are used. For this exercise, we restrict the sample to children who were assessed in all three survey waves. 
Table 3

Means of the Behavior Problems Index by Developmental Disabilities

\begin{tabular}{lccc}
\hline Behavior Problems Index (BPI) & $\begin{array}{c}\text { Sample } \\
\text { mean }\end{array}$ & $\begin{array}{c}\text { Developmental } \\
\text { delay }\end{array}$ & ADHD \\
\hline Total score & 106.0 & 116.0 & 119.1 \\
Hyperactive score & 106.4 & 114.1 & 116.1 \\
Antisocial score & 105.5 & 110.8 & 112.9 \\
Oppositional/Defiant score & 104.9 & 107.8 & 111.5 \\
Anxious/Depressed score & 106.4 & 112.8 & 112.6 \\
Peer problem score & 108.3 & 113.2 & 113.7 \\
\hline
\end{tabular}

Note: 1997, 2002-3, 2007 waves of the PSID-CDS are used. 


\section{Table 4}

Estimated Effects of Fetal Growth Rate on Ever-diagnosed Developmental Disabilities

\begin{tabular}{|c|c|c|c|c|c|c|}
\hline \multirow{2}{*}{$\begin{array}{l}\text { Ever-diagnosed developmental disability } \\
\text { Prevalence }\end{array}$} & \multicolumn{3}{|c|}{ Developmental delay } & \multicolumn{3}{|c|}{ ADHD } \\
\hline & & $9.08 \%$ & & & $10.05 \%$ & \\
\hline Log of FGR & $\begin{array}{l}-0.16^{* * *} \\
(0.06)\end{array}$ & $\begin{array}{l}-0.19^{* *} \\
(0.08)\end{array}$ & & $\begin{array}{l}-0.06 \\
(0.06)\end{array}$ & $\begin{array}{l}-0.12 \\
(0.09)\end{array}$ & \\
\hline Log of FGR $*$ male & & & $\begin{array}{l}-0.19^{*} \\
(0.11)\end{array}$ & & & $\begin{array}{l}-0.18 \\
(0.11)\end{array}$ \\
\hline $\log$ of FGR $*$ female & & & $\begin{array}{l}-0.20^{\text {** }} \\
(0.10)\end{array}$ & & & $\begin{array}{l}-0.05 \\
(0.09)\end{array}$ \\
\hline Gestational week 32-37 & $\begin{array}{l}-0.06^{* *} \\
(0.03)\end{array}$ & $\begin{array}{l}-0.00 \\
(0.04)\end{array}$ & $\begin{array}{l}-0.00 \\
(0.04)\end{array}$ & $\begin{array}{l}0.00 \\
(0.03)\end{array}$ & $\begin{array}{l}-0.02 \\
(0.06)\end{array}$ & $\begin{array}{l}-0.01 \\
(0.06)\end{array}$ \\
\hline Gestational week $<32$ & $\begin{array}{l}0.03 \\
(0.14)\end{array}$ & $\begin{array}{l}0.04 \\
(0.08)\end{array}$ & $\begin{array}{l}0.04 \\
(0.08)\end{array}$ & $\begin{array}{l}0.07 \\
(0.15)\end{array}$ & $\begin{array}{l}0.05 \\
(0.11)\end{array}$ & $\begin{array}{l}0.06 \\
(0.11)\end{array}$ \\
\hline $\mathrm{N}$ & 1464 & 1464 & 1464 & 1462 & 1462 & 1462 \\
\hline Adjusted R & 0.036 & 0.029 & 0.028 & 0.020 & 0.027 & 0.028 \\
\hline$F$ statistic & & & 0.00 & & & 1.56 \\
\hline$p$-value & & & 0.97 & & & 0.21 \\
\hline Mother FE & No & Yes & Yes & No & Yes & Yes \\
\hline
\end{tabular}

Note: 1997, 2002-3, 2007 waves of the PSID-CDS are used. N denotes the number of children. All regressions include the controls for child's sex, race, lifetime family income, mother's age and marital status at child's birth, cigarette excise tax at child birth, a set of indicators for birth order, home environment, and mother's education. Table shows F statistics and p-values for testing the equality of the coefficients on the two interaction terms (Log FGR*male and Log FGR*female). Robust standard errors in parentheses are clustered at the mother level.

*

$\mathrm{p}<0.1$,

** $\mathrm{p}<0.05$

$* * *$

$\mathrm{p}<0.01$. 
Table 5

Estimated Effects of Fetal Growth Rate on Behavior Problems Index (BPI)

\begin{tabular}{|c|c|c|c|c|c|c|c|c|c|}
\hline \multirow{2}{*}{$\begin{array}{l}\text { Behavior Problems Index (BPI) } \\
\text { Log of FGR }\end{array}$} & \multicolumn{3}{|c|}{ BPI total score } & \multicolumn{3}{|c|}{ Antisocial score } & \multicolumn{3}{|c|}{ Oppositional/Defiant score } \\
\hline & $\begin{array}{l}-1.27 \\
(2.62)\end{array}$ & $\begin{array}{l}-6.35^{*} \\
(3.47)\end{array}$ & & $\begin{array}{l}-1.43 \\
(2.13)\end{array}$ & $\begin{array}{l}-8.29^{* * *} \\
(2.68)\end{array}$ & & $\begin{array}{l}-0.98 \\
(1.79)\end{array}$ & $\begin{array}{l}-2.38 \\
(2.22)\end{array}$ & \\
\hline Log of FGR $*$ male & & & $\begin{array}{l}-6.63 \\
(4.07)\end{array}$ & & & $\begin{array}{l}-10.40^{* * * *} \\
(3.32)\end{array}$ & & & $\begin{array}{l}-4.96^{*} \\
(2.60)\end{array}$ \\
\hline Log of FGR $*$ female & & & $\begin{array}{l}-6.05 \\
(4.29)\end{array}$ & & & $\begin{array}{l}-6.07^{*} \\
(3.33)\end{array}$ & & & $\begin{array}{l}0.12 \\
(2.67)\end{array}$ \\
\hline Gestational week 32-37 & $\begin{array}{l}-0.97 \\
(1.64)\end{array}$ & $\begin{array}{l}-1.66 \\
(2.18)\end{array}$ & $\begin{array}{l}-1.64 \\
(2.19)\end{array}$ & $\begin{array}{l}1.21 \\
(1.35)\end{array}$ & $\begin{array}{l}-3.04^{*} \\
(1.76)\end{array}$ & $\begin{array}{l}-2.95^{*} \\
(1.76)\end{array}$ & $\begin{array}{l}0.30 \\
(1.20)\end{array}$ & $\begin{array}{l}-1.19 \\
(1.55)\end{array}$ & $\begin{array}{l}-1.08 \\
(1.56)\end{array}$ \\
\hline Gestational week < 32 & $\begin{array}{l}4.17 \\
(4.28)\end{array}$ & $\begin{array}{l}-0.23 \\
(4.90)\end{array}$ & $\begin{array}{l}-0.12 \\
(4.94)\end{array}$ & $\begin{array}{l}-1.97 \\
(4.08)\end{array}$ & $\begin{array}{l}-6.87^{* *} \\
(3.42)\end{array}$ & $\begin{array}{l}-5.83 \\
(3.56)\end{array}$ & $\begin{array}{l}-1.69 \\
(2.92)\end{array}$ & $\begin{array}{l}-3.19 \\
(3.18)\end{array}$ & $\begin{array}{l}-1.95 \\
(2.97)\end{array}$ \\
\hline $\mathrm{N}$ & 1406 & 1406 & 1406 & 1960 & 1960 & 1960 & 2269 & 2269 & 2269 \\
\hline Adjusted R & 0.046 & 0.384 & 0.383 & 0.076 & 0.230 & 0.230 & 0.053 & 0.109 & 0.109 \\
\hline$F$ statistic & & & 0.02 & & & 1.17 & & & 2.93 \\
\hline$p$-value & & & 0.90 & & & 0.28 & & & 0.09 \\
\hline Behavior Problems Index (BPI) & \multicolumn{3}{|c|}{ Hyperactive score } & \multicolumn{3}{|c|}{ Anxious/Depressed score } & \multicolumn{3}{|c|}{ Peer problem score } \\
\hline Log of FGR & $\begin{array}{l}-0.25 \\
(2.06)\end{array}$ & $\begin{array}{l}-3.78 \\
(2.48)\end{array}$ & & $\begin{array}{l}0.66 \\
(1.76)\end{array}$ & $\begin{array}{l}-0.16 \\
(2.70)\end{array}$ & & $\begin{array}{l}-1.57 \\
(1.81)\end{array}$ & $\begin{array}{l}-2.92 \\
(2.26)\end{array}$ & \\
\hline $\log$ of FGR $*$ male & & & $\begin{array}{l}-6.75^{* *} \\
(3.09)\end{array}$ & & & $\begin{array}{l}-2.19 \\
(3.15)\end{array}$ & & & $\begin{array}{l}-1.81 \\
(2.55)\end{array}$ \\
\hline Log of FGR $*$ female & & & $\begin{array}{l}-0.86 \\
(3.16)\end{array}$ & & & $\begin{array}{l}1.81 \\
(3.34)\end{array}$ & & & $\begin{array}{l}-4.02 \\
(3.04)\end{array}$ \\
\hline Gestational week 32-37 & $\begin{array}{l}1.45 \\
(1.21)\end{array}$ & $\begin{array}{l}-0.40 \\
(1.60)\end{array}$ & $\begin{array}{l}-0.28 \\
(1.57)\end{array}$ & $\begin{array}{l}-0.88 \\
(1.05)\end{array}$ & $\begin{array}{l}-1.30 \\
(1.34)\end{array}$ & $\begin{array}{l}-1.23 \\
(1.35)\end{array}$ & $\begin{array}{l}-1.54 \\
(1.04)\end{array}$ & $\begin{array}{l}-4.18^{* * * *} \\
(1.35)\end{array}$ & $\begin{array}{l}-4.23^{\text {**** }} \\
(1.36)\end{array}$ \\
\hline Gestational week < 32 & $\begin{array}{l}-0.75 \\
(3.96)\end{array}$ & $\begin{array}{l}-3.62 \\
(3.72)\end{array}$ & $\begin{array}{l}-2.17 \\
(4.04)\end{array}$ & $\begin{array}{l}2.21 \\
(3.58)\end{array}$ & $\begin{array}{l}2.08 \\
(4.46)\end{array}$ & $\begin{array}{l}3.05 \\
(4.33)\end{array}$ & $\begin{array}{l}-8.67^{* *} \\
(3.03)\end{array}$ & $\begin{array}{l}-7.60^{* *} \\
(3.01)\end{array}$ & $\begin{array}{l}-8.12^{\text {**** }} \\
(3.05)\end{array}$ \\
\hline $\mathrm{N}$ & 2253 & 2253 & 2253 & 2261 & 2261 & 2261 & 2012 & 2012 & 2012 \\
\hline Adjusted R & 0.089 & 0.151 & 0.152 & 0.058 & 0.070 & 0.069 & 0.118 & 0.108 & 0.108 \\
\hline$F$ statistic & & & 2.45 & & & 1.23 & & & 0.44 \\
\hline$p$-value & & & 0.12 & & & 0.27 & & & 0.51 \\
\hline Mother FE & No & Yes & Yes & No & Yes & Yes & No & Yes & Yes \\
\hline
\end{tabular}

Note: 1997, 2002-3, 2007 waves of the PSID-CDS are used. Regressions include repeated observations. N denotes the number of observations. All regressions include the controls for child's sex, race, lifetime family income, mother's age and marital status at child's birth, cigarette excise tax at child birth, a set of indicators for birth order, home environment, and mother's education. Table shows F-statistics and p-values for testing the equality of the coefficients on the two interaction terms (Log FGR*male and Log FGR*female).Robust standard errors in parentheses are clustered at the child level.

${ }^{*}<0.1$,

** $\mathrm{p}<0.05$,

*** $\mathrm{p}<0.01$. 


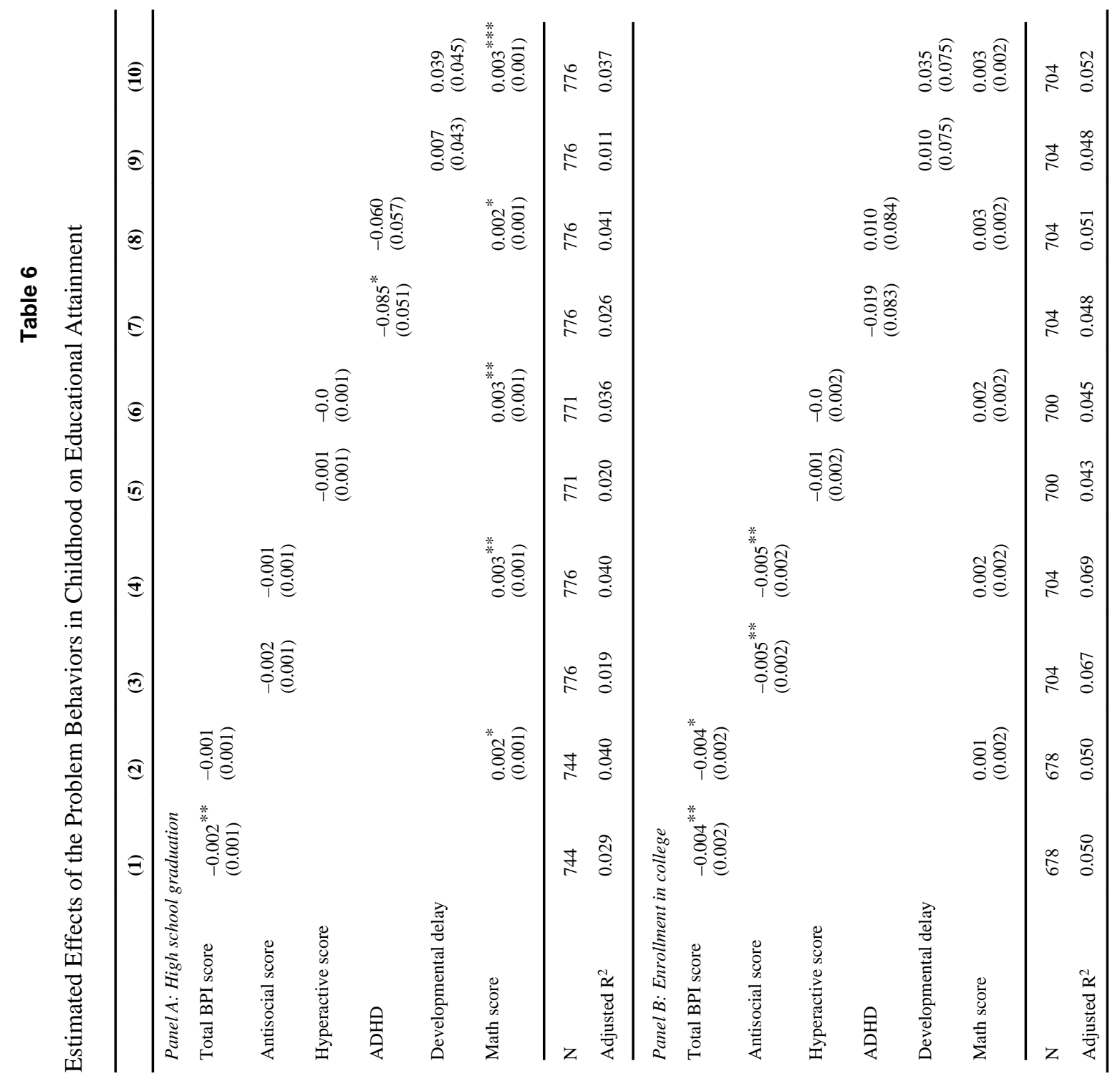




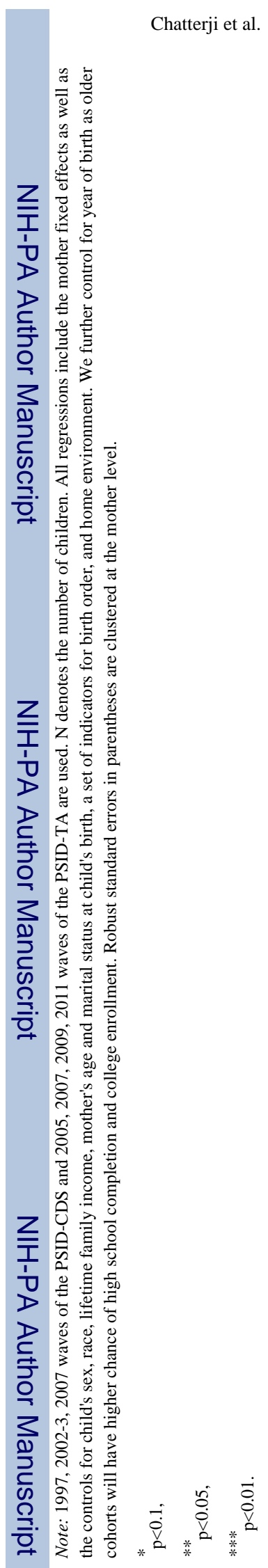

Econ Hum Biol. Author manuscript; available in PMC 2015 December 01. 


\section{Appendix Table 1}

Estimated Effects of Fetal Growth on Ever-diagnosed Developmental Disabilities

\begin{tabular}{|c|c|c|c|c|}
\hline \multirow{3}{*}{$\begin{array}{l}\text { Ever-diagnosed development disability } \\
\text { Prevalence } \\
\text { Log of birth weight }\end{array}$} & \multirow{2}{*}{\multicolumn{2}{|c|}{$\frac{\text { Developmental delay }}{9.08 \%}$}} & \multirow{2}{*}{\multicolumn{2}{|c|}{$\begin{array}{c}\text { ADHD } \\
10.05 \%\end{array}$}} \\
\hline & & & & \\
\hline & $\begin{array}{l}-0.10^{* *} \\
(0.05)\end{array}$ & $\begin{array}{l}-0.16^{* *} \\
(0.07)\end{array}$ & $\begin{array}{l}-0.06 \\
(0.05)\end{array}$ & $\begin{array}{c}-0.09 \\
(0.07)\end{array}$ \\
\hline $\mathrm{N}$ & 1464 & 1464 & 1462 & 1462 \\
\hline Adjusted R & 0.032 & 0.029 & 0.020 & 0.027 \\
\hline Low birth weight & $\begin{array}{l}0.08^{* * *} \\
(0.03)\end{array}$ & $\begin{array}{l}0.11^{* *} \\
(0.05)\end{array}$ & $\begin{array}{l}0.05 \\
(0.03)\end{array}$ & $\begin{array}{l}0.03 \\
(0.05)\end{array}$ \\
\hline $\mathrm{N}$ & 1464 & 1464 & 1462 & 1462 \\
\hline Adjusted R & 0.033 & 0.028 & 0.021 & 0.024 \\
\hline Very low birth weight & $\begin{array}{l}0.18 \\
(0.13)\end{array}$ & $\begin{array}{l}0.28^{* *} \\
(0.13)\end{array}$ & $\begin{array}{l}0.13 \\
(0.13)\end{array}$ & $\begin{array}{l}0.27^{* *} \\
(0.12)\end{array}$ \\
\hline $\mathrm{N}$ & 1464 & 1464 & 1462 & 1462 \\
\hline Adjusted R & 0.030 & 0.029 & 0.020 & 0.032 \\
\hline Log of fetal growth rate & $\begin{array}{l}-0.14^{* *} \\
(0.05)\end{array}$ & $\begin{array}{l}-0.20 * * \\
(0.08)\end{array}$ & $\begin{array}{l}-0.07 \\
(0.06)\end{array}$ & $\begin{array}{c}-0.12 \\
(0.08)\end{array}$ \\
\hline $\mathrm{N}$ & 1464 & 1464 & 1462 & 1462 \\
\hline Adjusted R & 0.034 & 0.030 & 0.021 & 0.028 \\
\hline Gestational week 32-37 & $\begin{array}{l}-0.02 \\
(0.03)\end{array}$ & $\begin{array}{l}0.03 \\
(0.04)\end{array}$ & $\begin{array}{l}0.02 \\
(0.03)\end{array}$ & $\begin{array}{l}0.00 \\
(0.06)\end{array}$ \\
\hline Gestational week <32 & $\begin{array}{l}0.11 \\
(0.14)\end{array}$ & $\begin{array}{l}0.13 \\
(0.10)\end{array}$ & $\begin{array}{l}0.10 \\
(0.14)\end{array}$ & $\begin{array}{l}0.10 \\
(0.09)\end{array}$ \\
\hline $\mathrm{N}$ & 1464 & 1464 & 1462 & 1462 \\
\hline Adjusted R & 0.028 & 0.021 & 0.019 & 0.024 \\
\hline Mother FE & No & Yes & No & Yes \\
\hline
\end{tabular}

Note: 1997, 2002-3, 2007 waves of the PSID-CDS are used. N denotes the number of children. All regressions include the controls for child's sex, race, lifetime family income, mother's age and marital status at child's birth, cigarette excise tax at child birth, a set of indicators for birth order, home environment, and mother's education. Robust standard errors in parentheses are clustered at the mother level.

$* \mathrm{p}<0.1$

$* * * \mathrm{p}<0.01$.

$* *$

$\mathrm{p}<0.05$ 


\section{Appendix Table 2}

Estimated Effects of Fetal Growth on Behavior Problems Index (BPI)

\begin{tabular}{|c|c|c|c|c|c|c|}
\hline \multirow{2}{*}{$\begin{array}{l}\text { Behavior Problems Index (BPI) } \\
\text { Log of birth weight }\end{array}$} & \multicolumn{2}{|c|}{ BPI total score } & \multicolumn{2}{|c|}{ Antisocial score } & \multicolumn{2}{|c|}{ Oppositional score } \\
\hline & $\begin{array}{l}-1.43 \\
(2.07)\end{array}$ & $\begin{array}{l}-4.75^{*} \\
(2.62)\end{array}$ & $\begin{array}{l}-1.79 \\
(1.70)\end{array}$ & $\begin{array}{l}-3.41^{*} \\
(2.07)\end{array}$ & $\begin{array}{c}-0.97 \\
(1.44)\end{array}$ & $\begin{array}{l}-0.77 \\
(1.95)\end{array}$ \\
\hline $\mathrm{N}$ & 1406 & 1406 & 1960 & 1960 & 2269 & 2269 \\
\hline Adjusted R & 0.047 & 0.385 & 0.076 & 0.228 & 0.054 & 0.110 \\
\hline Low birth weight & $\begin{array}{l}2.82^{*} \\
(1.57)\end{array}$ & $\begin{array}{l}1.79 \\
(1.85)\end{array}$ & $\begin{array}{l}2.18 \\
(1.36)\end{array}$ & $\begin{array}{l}-0.13 \\
(1.90)\end{array}$ & $\begin{array}{l}1.57 \\
(1.06)\end{array}$ & $\begin{array}{l}0.96 \\
(1.27)\end{array}$ \\
\hline $\mathrm{N}$ & 1406 & 1406 & 1960 & 1960 & 2269 & 2269 \\
\hline Adjusted R & 0.049 & 0.384 & 0.077 & 0.227 & 0.055 & 0.110 \\
\hline Very low birth weight & $\begin{array}{l}1.68 \\
(5.78)\end{array}$ & $\begin{array}{l}8.07^{*} \\
(4.34)\end{array}$ & $\begin{array}{l}2.25 \\
(3.59)\end{array}$ & $\begin{array}{l}1.51 \\
(1.71)\end{array}$ & $\begin{array}{l}-0.08 \\
(4.56)\end{array}$ & $\begin{array}{l}-2.76 \\
(2.84)\end{array}$ \\
\hline $\mathrm{N}$ & 1406 & 1406 & 1960 & 1960 & 2269 & 2269 \\
\hline Adjusted R & 0.047 & 0.385 & 0.076 & 0.227 & 0.054 & 0.110 \\
\hline Log of fetal growth rate & $\begin{array}{l}-1.26 \\
(2.44)\end{array}$ & $\begin{array}{l}-5.56^{*} \\
(3.12)\end{array}$ & $\begin{array}{l}-1.74 \\
(1.98)\end{array}$ & $\begin{array}{l}-5.84^{* *} \\
(2.42)\end{array}$ & $\begin{array}{l}-0.86 \\
(1.68)\end{array}$ & $\begin{array}{l}-1.43 \\
(2.18)\end{array}$ \\
\hline $\mathrm{N}$ & 1406 & 1406 & 1960 & 1960 & 2269 & 2269 \\
\hline Adjusted R & 0.047 & 0.385 & 0.076 & 0.229 & 0.054 & 0.110 \\
\hline Gestational week 32-37 & $\begin{array}{l}-0.65 \\
(1.59)\end{array}$ & $\begin{array}{l}-0.57 \\
(2.07)\end{array}$ & $\begin{array}{l}1.55 \\
(1.28)\end{array}$ & $\begin{array}{l}-1.55 \\
(1.66)\end{array}$ & $\begin{array}{l}0.52 \\
(1.15)\end{array}$ & $\begin{array}{l}-0.75 \\
(1.51)\end{array}$ \\
\hline Gestational week < 32 & $\begin{array}{l}4.59 \\
(4.16)\end{array}$ & $\begin{array}{l}2.66 \\
(5.33)\end{array}$ & $\begin{array}{l}-1.17 \\
(3.88)\end{array}$ & $\begin{array}{l}-2.84 \\
(2.68)\end{array}$ & $\begin{array}{l}-1.22 \\
(2.75)\end{array}$ & $\begin{array}{l}-2.07 \\
(3.04)\end{array}$ \\
\hline $\mathrm{N}$ & 1406 & 1406 & 1960 & 1960 & 2269 & 2269 \\
\hline Adjusted R & 0.047 & 0.383 & 0.076 & 0.227 & 0.054 & 0.110 \\
\hline Behavior Problems Index (BPI) & \multicolumn{2}{|c|}{ Hyperactive score } & \multicolumn{2}{|c|}{ Anxious/Depressed score } & \multicolumn{2}{|c|}{ Peer problem score } \\
\hline Log of birth weight & $\begin{array}{l}-1.06 \\
(1.69)\end{array}$ & $\begin{array}{l}-2.56 \\
(1.92)\end{array}$ & $\begin{array}{l}0.43 \\
(1.45)\end{array}$ & $\begin{array}{l}-0.27 \\
(2.34)\end{array}$ & $\begin{array}{l}0.48 \\
(1.45)\end{array}$ & $\begin{array}{l}1.12 \\
(1.94)\end{array}$ \\
\hline $\mathrm{N}$ & 2253 & 2253 & 2261 & 2261 & 2012 & 2012 \\
\hline Adjusted R & 0.090 & 0.153 & 0.058 & 0.070 & 0.118 & 0.107 \\
\hline Low birth weight & $\begin{array}{l}3.23^{* * *} \\
(1.12)\end{array}$ & $\begin{array}{l}1.06 \\
(1.45)\end{array}$ & $\begin{array}{l}1.47 \\
(1.04)\end{array}$ & $\begin{array}{l}2.07 \\
(1.36)\end{array}$ & $\begin{array}{l}2.46^{* *} \\
(1.13)\end{array}$ & $\begin{array}{l}0.29 \\
(1.49)\end{array}$ \\
\hline $\mathrm{N}$ & 2253 & 2253 & 2261 & 2261 & 2012 & 2012 \\
\hline Adjusted R & 0.092 & 0.153 & 0.059 & 0.071 & 0.119 & 0.107 \\
\hline Very low birth weight & $\begin{array}{l}3.10 \\
(5.18)\end{array}$ & $\begin{array}{l}3.83 \\
(3.73)\end{array}$ & $\begin{array}{l}-2.11 \\
(4.01)\end{array}$ & $\begin{array}{l}-1.62 \\
(4.22)\end{array}$ & $\begin{array}{l}-1.47 \\
(3.89)\end{array}$ & $\begin{array}{l}-2.04 \\
(3.00)\end{array}$ \\
\hline $\mathrm{N}$ & 2253 & 2253 & 2261 & 2261 & 2012 & 2012 \\
\hline Adjusted R & 0.090 & 0.153 & 0.058 & 0.070 & 0.118 & 0.107 \\
\hline Log of fetal growth rate & $\begin{array}{c}-0.84 \\
(1.98)\end{array}$ & $\begin{array}{l}-3.11 \\
(2.28)\end{array}$ & $\begin{array}{l}0.70 \\
(1.68)\end{array}$ & $\begin{array}{l}0.00 \\
(2.71)\end{array}$ & $\begin{array}{l}0.31 \\
(1.71)\end{array}$ & $\begin{array}{l}-0.11 \\
(2.25)\end{array}$ \\
\hline $\mathrm{N}$ & 2253 & 2253 & 2261 & 2261 & 2012 & 2012 \\
\hline Adjusted R & 0.089 & 0.153 & 0.058 & 0.070 & 0.118 & 0.107 \\
\hline Gestational week 32-37 & $\begin{array}{l}1.46 \\
(1.17)\end{array}$ & $\begin{array}{l}0.30 \\
(1.53)\end{array}$ & $\begin{array}{l}-1.04 \\
(1.01)\end{array}$ & $\begin{array}{l}-1.24 \\
(1.29)\end{array}$ & $\begin{array}{l}-1.26 \\
(0.97)\end{array}$ & $\begin{array}{l}-3.66^{* * * *} \\
(1.32)\end{array}$ \\
\hline
\end{tabular}

Econ Hum Biol. Author manuscript; available in PMC 2015 December 01. 


\begin{tabular}{lllllll}
\hline Behavior Problems Index (BPI) & \multicolumn{2}{c}{ BPI total score } & \multicolumn{3}{c}{ Antisocial score } & \multicolumn{2}{c}{ Oppositional score } \\
\hline Gestational week < 32 & -0.63 & -1.83 & 1.94 & 2.15 & $-7.91^{* * *}$ & $-6.21^{* *}$ \\
& $(3.91)$ & $(3.54)$ & $(3.56)$ & $(4.71)$ & $(2.94)$ & $(3.04)$ \\
$\mathrm{N}$ & 2253 & 2253 & 2261 & 2261 & 2012 & 2012 \\
Adjusted R & 0.090 & 0.152 & 0.058 & 0.070 & 0.119 & 0.108 \\
\hline
\end{tabular}

Note: 1997, 2002-3, 2007 waves of the PSID-CDS are used. Regressions include repeated observations. N denotes the number of observations. All regressions include the controls for child's sex, race, lifetime family income, mother's age and marital status at child's birth, cigarette excise tax at child birth, a set of indicators for birth order, home environment, and mother's education. Robust standard errors in parentheses are clustered at the child level.

${ }^{*}<<0.1$,
${ }^{* *} \mathrm{p}<0.05$,
$\stackrel{* *}{\mathrm{p}}<0.01$. 


\section{Appendix Table 3}

Estimated Effects of Fetal Growth Rate on Speech and Sensory Impairment

\begin{tabular}{|c|c|c|c|c|c|c|c|c|c|}
\hline \multirow{2}{*}{$\begin{array}{l}\text { Ever-diagnosed } \\
\text { developmental disability } \\
\text { Prevalence }\end{array}$} & \multicolumn{3}{|c|}{ Speech impairment } & \multicolumn{3}{|c|}{ Hearing impairment } & \multicolumn{3}{|c|}{ Vision difficulty } \\
\hline & & $10.86 \%$ & & & $3.76 \%$ & & & $6.90 \%$ & \\
\hline $\log$ of FGR & $\begin{array}{c}-0.02 \\
(0.06)\end{array}$ & $\begin{array}{l}-0.15^{* *} \\
(0.08)\end{array}$ & & $\begin{array}{l}0.02 \\
(0.03)\end{array}$ & $\begin{array}{l}0.08^{*} \\
(0.04)\end{array}$ & & $\begin{array}{l}-0.02 \\
(0.05)\end{array}$ & $\begin{array}{l}-0.04 \\
(0.07)\end{array}$ & \\
\hline Log of FGR * male & & & $\begin{array}{l}-0.15 \\
(0.10)\end{array}$ & & & $\begin{array}{l}0.09 \\
(0.06)\end{array}$ & & & $\begin{array}{l}-0.09 \\
(0.08)\end{array}$ \\
\hline $\log$ of FGR $*$ female & & & $\begin{array}{l}-0.16^{*} \\
(0.09)\end{array}$ & & & $\begin{array}{l}0.07 \\
(0.05)\end{array}$ & & & $\begin{array}{l}0.01 \\
(0.09)\end{array}$ \\
\hline Gestational week 32-37 & $\begin{array}{l}0.02 \\
(0.04)\end{array}$ & $\begin{array}{l}-0.01 \\
(0.06)\end{array}$ & $\begin{array}{l}-0.01 \\
(0.06)\end{array}$ & $\begin{array}{c}-0.02 \\
(0.02)\end{array}$ & $\begin{array}{l}-0.02 \\
(0.03)\end{array}$ & $\begin{array}{l}-0.02 \\
(0.03)\end{array}$ & $\begin{array}{l}-0.03 \\
(0.03)\end{array}$ & $\begin{array}{l}-0.05 \\
(0.05)\end{array}$ & $\begin{array}{l}-0.05 \\
(0.05)\end{array}$ \\
\hline Gestational week $<32$ & $\begin{array}{l}0.01 \\
(0.13)\end{array}$ & $\begin{array}{l}-0.12 \\
(0.12)\end{array}$ & $\begin{array}{l}-0.13 \\
(0.12)\end{array}$ & $\begin{array}{l}0.04 \\
(0.07)\end{array}$ & $\begin{array}{l}-0.08 \\
(0.09)\end{array}$ & $\begin{array}{l}-0.09 \\
(0.10)\end{array}$ & $\begin{array}{l}0.34^{* *} \\
(0.15)\end{array}$ & $\begin{array}{l}0.35^{* *} \\
(0.15)\end{array}$ & $\begin{array}{l}0.36^{* *} \\
(0.15)\end{array}$ \\
\hline $\mathrm{N}$ & 1464 & 1464 & 1464 & 1464 & 1464 & 1464 & 1464 & 1464 & 1464 \\
\hline Adjusted $\mathrm{R}^{2}$ & 0.027 & 0.066 & 0.066 & -0.0 & 0.004 & 0.003 & 0.025 & 0.029 & 0.030 \\
\hline F statistics & & & 0.01 & & & 0.05 & & & 0.82 \\
\hline$p$-value & & & 0.92 & & & 0.82 & & & 0.37 \\
\hline
\end{tabular}

Note: 1997, 2002-3, 2007 waves of the PSID-CDS are used. N denotes the number of children. All regressions include the controls for child's sex, race, lifetime family income, mother's age and marital status at child's birth, cigarette excise tax at child birth, a set of indicators for birth order, home environment, and mother's education. Table shows F-statistics and p-values for testing the equality of the coefficients on the two interaction terms (Log FGR*male and Log FGR*female). Robust standard errors in parentheses are clustered at the mother level.

$$
\begin{aligned}
& \text { *** } \mathrm{p}<0.01 . \\
& * \mathrm{p}<0.1, \\
& * * \\
& \mathrm{p}<0.05,
\end{aligned}
$$

